\title{
A RÖVIDÍTETT HÁZASTÁRSI STRESSZ SKÁLA PSZICHOMETRIAI JELLEMZÓI
}

\author{
BALOG PIROSKA $^{1 *}$ - SZÉKELY ANDREA ${ }^{2}$ - \\ SZABÓ GÁBOR ${ }^{1}$ - KOPP MÁRIA ${ }^{1}$

\begin{abstract}
${ }^{1}$ Semmelweis Egyetem, Magatartástudományi Intézet, Budapest
${ }^{2}$ Gottsegen György Országos Kardiológiai Intézet, Budapest
\end{abstract}

(Beérkezett: 2006. július 19.; elfogadva: 2006. július 25.)

Célkitûzés: A Gottsegen György Országos Kardiológiai Intézet Kockázat Vizsgálatának célja elsôsorban a nyitott szívmútéten átesett betegek pszichoszociális kockázati tényezóinek vizsgálata és követése. Módszer: 137, nyitott szívmútéten átesett betegnél (87 férfi és 50 nô) a 17 tételes Házastársi Stressz Skála magyar változata a mútét után két évvel került felvételre, majd a kérdôív Varimax rotációval történó faktoranalízisét követően teszteltük a kérdốiv rövidített változatát is. Eredmények: A 17 tételes Házastársi Stressz Skála (Cronbachalfa 0,77) a faktoranalízis során öt különálló dimenziót eredményezett: a szeretet-bizalom, a problémák, a szexuális kapcsolat, a szívbetegség hatása a szexualitásra, valamint a személyes identitás faktorokat. A tételek az egyes dimenziókban jól elkülönültek, mindössze két tételt találtunk, melyek nem egyértelmúen tartoztak egy faktorhoz, ezeket a rövidítés során kihagytuk. A kiválasztott Rövidített Házastársi Stressz Skála öt tételének (három kérdés az elsố faktorból, egy a másodikból, egy az ötödikból) skálaösszege korrelált a 17 tétel skálaösszegével $(r=0,902, p<0,001)$, belsó konzisztenciája megfeleló (Cronbach-alfa 0,69). Konklúzió: A Rövidített Házastársi Stressz Skála pszichometriai jellemzói megfelelőek.

Kulcsszavak: nyitott szívmútét, házastársi stressz, faktoranalízis, Rövidített Házastársi Stressz Skála, pszichometriai jellemzók

A házastársi stressz több úton is hozzájárulhat az egészség romlásához: indirekt úton a pszichiátriai zavarok, depresszió, szorongás elófordulási gyakoriságának, intenzitásának növekedésével, valamint az egészségkárosító magatartásformák útján (gyógyszer- és alkoholabúzus, elhízás,

* Levelezô szerzô: Balog Piroska, Semmelweis Egyetem, Magatartástudományi Intézet, 1089 Budapest, Nagyvárad tér 4. E-mail: balopir@net.sote.hu 
rossz étkezési szokások), ugyanakkor direkt úton, a szív-érrendszer, a neuro-, endokrin- és immunrendszer fiziológiai folyamataira hatva (Robles és Kiekolt-Glaser 2003). A házasság minósége, múködési jellemzói fiziológiai változásokkal járnak, és ennek hosszú távú következményei az egészségi állapot változásaiban is megmutatkozhatnak. A házastársi stressz a kardiovaszkuláris beteg nóknél erôteljesen rontotta a betegség prognózisát (Orth-Gomer és mtsai 2000). Baker és munkatársai (2000) longitudinális tanulmányának eredményei szerint a házassággal való elégedetlenség szignifikánsan együtt járt a szív falának megvastagodásával és magasabb vérnyomásértékekkel. A házastárs egyszerú jelenléte ugyanis nem feltétlenül protektív: egy problémás házasság önmagában stresszforrás, ugyanakkor limitálja a házastársak más kapcsolatokból való támogatáskeresési lehetôségeit (Blom és mtsai 2003). Mind nóknél, mind férfiaknál leírják, hogy a házastársi konfliktusokkal együtt járó negatív, ellenséges viselkedést követi a stresszhormonszint és a kardiovaszkuláris reaktivitás megemelkedése, valamint az immunfunkciók csökkenése. Ötéves utánkövetés eredményei azt mutatják, hogy az egyidejúleg kettős (házastársi és munkahelyi) stressznek való kitettség jelenti a legnagyobb kockázatot (Krantz és Östergren 2001), és rontja legjobban a szívmútéten átesett nók prognózisát (Orth-Gomer és Leineweber 2005).

A jó házastársi kapcsolat viszont jó egészségi állapottal jár. Egy négyéves utánkövetéses vizsgálat eredményei azt mutatták, hogy akik a házasságuk minóségével elégedettek voltak, szignifikánsan kevesebb fizikai tünetról, panaszról számoltak be, mint azok, akik elégedetlenek voltak. Ugyanakkor azon házastársaknál, akiknek házassága javult a négy év alatt, ezzel egyidejúleg nagymértében csökkent a fizikai panaszaik száma is (Wickrama és mtsai 1997). A családi támogatással való elégedettség - azaz a pozitív partneri, családi támogatás - a rosszindulatú melldaganatos nók depresszióját is nagymértékben csökkentette (Balog és Dégi 2005). Hároméves utánkövetéses vizsgálatban, hemodialízissel kezelt vesebetegek körében a párkapcsolati elégedettség 29\%-kal csökkentette a mortalitás kockázatát, míg a kapcsolattal szembeni negatív beállítódás $46 \%$-kal növelte a mortalitás kockázatát, akkor is, ha a betegség súlyosságára, a terápiára, valamint a demográfiai változókra is kontrollálták az adataikat (Kimmel és mtsai 2000).

A nemzetközi szakirodalom fényében a házastársi stressz és az egészségi állapot összefüggéseinek mérését magyar populáción is indokoltnak tartottuk, viszont sem a magyar nyelvú szakirodalomban, sem nemzetközi folyóiratokban nem találkoztunk magyar populáción végzett hasonló kutatásokkal, sem magyar méróeszközzel. Ezért a hivatalos fordítás szabályainak megfelelóen lefordítottuk a kérdőivet, majd beépítettük az Országos Kardiológiai Intézet Kockázat Vizsgálatának kérdőívcsomagjába. 


\section{CÉLKITÛZŹS}

Az Országos Kardiológiai Intézet Kockázat Vizsgálatának célja elsősorban a szívmútéten átesett betegek pszichoszociális kockázati tényezóinek vizsgálata és követése, a mútét utáni depresszió és alvászavarok prediktorainak kimutatása. A mútét után két évvel felvett 17 tételes Házastársi Stressz Skála magyar változata szintén részét képezte a vizsgálatnak, ennek célja a skála pszichometriai jellemzóinek feltárása volt.

\section{MÓDSZER}

\section{Vizsgálati személyek}

Az Etikai Bizottság engedélyét és a személyes írásos beleegyezést követôen 2000 májusa és 2001 júliusa között nyitott szívmútétre elójegyzett betegeket vizsgáltunk a felnótt szívsebészeti osztályon, prospektív módszerrel.

180 szívmútéten átesett betegnél mútét elôtt, majd a mútét után 6 héttel, fél évvel, egy évvel, két évvel, és három évvel vizsgálták a betegségük súlyosságát jelzó fiziológiai mutatókat, az intra- és posztoperatív adatokat, a szövődményeket, az intenzív osztályos és a kórházi tartózkodás hosszát, a társbetegségeket, valamint - a hagyományos kockázati tényezók mellett - a pszichoszociális kockázati tényezóket. A két évvel késóbbi kérdôívcsomagba beillesztettük a Házastársi Stressz Skála magyar változatát (17 kérdés), a kérdőív pszichometriai jellemzóinek vizsgálata céljából.

A vizsgálat megkezdésekor a visszautasítási ráta $20 \%$-os volt. A két évvel késóbbi utánkövetésre lemorzsolódott további 23,9\%, amelyból 13 beteg $(7,2 \%)$ meghalt, további 30 beteg (a megmaradtak 18,0\%-a) utasította vissza a vizsgálatban való észvételt. A felmérést visszautasítók elsósorban idóhiányra hivatkoztak, és fóként az alacsony iskolázottságúak köréból kerültek ki (a visszautasítás tehát nem a magas depresszióval volt összefüggésben, ahogyan azt a kutatás vezetói korábban feltételezték).

Így tehát összesen 137 szívmútéten átesett beteg házastársi stressz jellemzőit vizsgáltuk, két évvel a mútétet követôen. Mivel a Házastársi Stressz Kérdóívet a Stockholmi Nói Koronária Kockázat Vizsgálatban dolgozták ki, a kérdốiv magyar változatát szintén szívbetegeknél, a Kardiológiai Intézet Kockázat Vizsgálata betegeinek körében próbáltuk ki, és vizsgáltuk a kérdôív belsó struktúráját. A további felhasználás érdekében teszteltük a skála rövidített változatát is. 


\begin{abstract}
Alkalmazott méróeszköz
A házastársi stressz mérése a Stockholmi Nói Koronária Kockázat Vizsgálatban strukturált interjúval történt. A skála pszichometriai jellemzóit 300 nő́n vizsgálták, és a belsô konzisztenciáját megfelelőnek találták (Cronbach-alfa: 0,77) (Orth-Gomer és Chesney 1997; Orth-Gomer és mtsai 2000). A skála 17 kérdést tartalmaz, melyek a házastársi kapcsolatból származó stresszforrásokra kérdeznek rá.

A kérdôív magyar változatát használtuk az Országos Kardiológiai Intézet Kockázat Vizsgálatában. A kérdőív fordítását és magyar változatát a hivatalos irányelveknek megfelelóen végeztük (Wild és mtsai 2005). A „marital stress” fogalmát a kérdőív magyar fordításakor munkatársaimmal (három fordítás angol nyelvról magyar nyelvre, majd egy visszafordítás) megegyezésben „házastársi stressz"-re fordítottuk. Az Országh László szerkesztette angol-magyar szótár szerint a "marital” első jelentése 'férji', majd a második jelentése 'házassági' és 'házastársi'. A „férji stressz" kifejezés nagyon egyoldalúvá tette volna az értelmezést, nem hagyott volna teret a nemi különbségek elemzésére. A "házassági stressz" jelentése implikálhatja a házasság jogi intézményét, mivel azonban a kérdőív elsôsorban a kapcsolat minóségére kérdez rá, ezért helyénvalóbbnak találtuk a "házastársi stressz" kifejezést, ahol megjelenik a "társi” viszony. "Párkapcsolati stressz"-nek is fordíthattuk volna, ez a kifejezés viszont nagyon tág, az udvarlástól az együttjáráson át a házasságon kívüli kapcsolatok is beleérthetóek, ezért maradtunk a "házastársi stressz" fogalmánál, ugyanis a kérdőív az együtt élő párok kapcsolati minőségét méri.

A kérdések tehát a párkapcsolat minőségére vonatkoznak: milyen ez - inkább szeretô, vagy barátságos, vagy rutinos, vagy nagyon problematikus? A szabadidejüket együtt töltik-e? Van-e a válaszadónak „külön élete” a házasságon kívül? Úgy érzi-e, hogy házastársa az ô legközelebbi bizalmasa? Úgy érzi-e, hogy ố a házastársa legközelebbi bizalmasa? Vannake dolgok, amelyekról nem tudnak nyíltan beszélni egymással? Voltak-e komoly problémák vagy krízisek a kapcsolatban? A kríziseket hútlenség, abúzus, anyagi nehézségek, betegség vagy más problémák okozták-e?
\end{abstract}

\title{
Alkalmazott statisztikai eljárás
}

Ebben a vizsgálatban az alkalmazott statisztikai eljárás a faktoranalízis (fốkomponens elemzés, Varimax rotáció), melynek alapján feltártuk a 17 tételes Házastársi Stressz Skála belsố struktúráját. 
Egy korábbi pilot vizsgálat alapján alakítottuk ki a skála rövidített változatát. A rövidítésnél két szempontot vettünk figyelembe: hogy a kiválasztott tételek magasan korreláljanak az eredeti faktorértékekkel, valamint hogy tartalmilag jól lefedjék a faktor jelentését. Ebben a vizsgálatban egy 137 fős mintán is teszteltük a Rövidített Házastársi Stressz Skála megbízhatóságát, és az eredeti skálával való egyezőségét.

\section{EREDMÉNYEK}

A vizsgált betegek átlagéletkora 58,6 év volt, a legfiatalabb 23, míg a legidôsebb 79 éves.

A 17 tételes Házastársi Stressz Skála a faktoranalízis (fókomponens elemzés, Varimax rotáció) során öt különálló dimenziót eredményezett (1. táblázat).

I. Az elsố struktúrához tartozó kérdések (szeretet-bizalom faktor):

- HS7. Házastársa (élettársa) az önhöz legközelebb álló személy, bizalmasa?

- HS8. Házastársa (élettársa) Önt tartja a hozzá legközelebb álló személynek (bizalmasának)?

- HS13. Problémáikat közösen szokták megoldani?

- HS1. Kapcsolata a házastársával (élettársával) szeretetteli?

- HS5. Házastársával (élettársával) közösen töltik szabadidejüket?

- HS2. Kapcsolata a házastársával (élettársával) baráti?

- HS3. Kapcsolata a házastársával rutinos (inkább megszokott)?

II. A második struktúra kérdései (probléma faktor):

- HS12. Kapcsolatukban voltak komolyabb krízisek?

- HS10. Voltak korábban komoly problémák a kapcsolatukban?

- HS11. Jelenleg vannak a házastársával való kapcsolatában komolyabb problémák?

- HS4. Kapcsolata a házastársával problematikus?

III. A harmadik struktúrát alkotó kérdések (szexualitás faktor):

- HS14. Van szexuális kapcsolata a házastársával?

- HS15. Kielégítónek találja a szexuális kapcsolatukat?

IV. A negyedik struktúra kérdései (szívbetegség hatása a szexualitásra):

- HS16. Szívbetegsége befolyásolta szexuális kapcsolatukat?

- HS17. Szívbetegsége miatt megszúnt a szexuális kapcsolatuk? 
V. Az ötödik struktúra (személyes identitás vagy egyéniség megtartása):

- HS9. Vannak dolgok, amelyekról nem tudnak nyiltan beszélni egymással?

- HS6. Van saját magánélete a házastársával való kapcsolaton kívül?

Az öt faktor tehát:

1. szeretet, bizalom

2. problémák

3. szexuális kapcsolat

4. szívbetegség hatása a szexualitásra

5. személyes identitás

1. táblázat. A faktorokat alkotó kérdéscsoportok

\begin{tabular}{|l|r|r|r|r|r|}
\hline HS7 & $\mathbf{0 , 9 4 5}$ & 0,054 & 0,144 & 0,032 & $-0,018$ \\
\hline HS8 & $\mathbf{0 , 9 4 5}$ & 0,054 & 0,144 & 0,032 & $-0,018$ \\
\hline HS13 & $\mathbf{0 , 9 4 0}$ & $-0,018$ & 0,124 & $-0,030$ & 0,041 \\
\hline HS1 & $\mathbf{0 , 9 1 5}$ & $-0,115$ & 0,003 & 0,046 & $-0,017$ \\
\hline HS5 & $\mathbf{0 , 9 0 3}$ & $-0,105$ & 0,028 & 0,053 & $-0,069$ \\
\hline HS2 & $\mathbf{0 , 8 3 7}$ & $-0,226$ & 0,021 & $-0,031$ & 0,177 \\
\hline HS3 & $\mathbf{0 , 4 5 3}$ & 0,320 & $-0,141$ & $-0,048$ & 0,345 \\
\hline HS12 & $-0,060$ & $\mathbf{0 , 8 9 9}$ & 0,109 & 0,033 & $-0,046$ \\
\hline HS10 & 0,061 & $\mathbf{0 , 8 3 3}$ & 0,069 & 0,142 & 0,061 \\
\hline HS11 & $-0,226$ & $\mathbf{0 , 6 5 2}$ & $-0,038$ & 0,241 & 0,412 \\
\hline HS4 & $-0,208$ & $\mathbf{0 , 5 7 4}$ & $-0,007$ & 0,046 & 0,511 \\
\hline HS14 & 0,093 & 0,168 & $\mathbf{0 , 8 9 5}$ & 0,049 & $-0,027$ \\
\hline HS15 & 0,140 & $-0,034$ & $\mathbf{0 , 8 7 9}$ & 0,019 & $-0,025$ \\
\hline HS16 & 0,050 & 0,081 & 0,220 & $\mathbf{0 , 8 7 9}$ & 0,000 \\
\hline HS17 & 0,008 & 0,181 & $-0,138$ & $\mathbf{0 , 8 7 7}$ & 0,082 \\
\hline HS9 & $-0,047$ & 0,004 & 0,013 & $-0,053$ & $\mathbf{0 , 8 2 9}$ \\
\hline HS6 & 0,258 & 0,144 & $-0,048$ & 0,151 & $\mathbf{0 , 4 7 9}$ \\
\hline
\end{tabular}

Az öt faktor a teljes variancia 75,8\%-át megmagyarázza, amely igen jó eredménynek számít. A tételek az egyes dimenziókban jól elkülönültek, mindössze két tételt találtunk, melyek nem egyértelmúen egy faktorhoz tartoztak, több faktorban is értékelhetô súllyal szerepeltek. A HS3, amely az 1 . faktor mellett a 2. és az 5. faktorral is 0,3-nál szorosabb együttjárást mutatott., valamint a HS4, amely a 2. faktor mellett az 5 . faktorban is hasonló faktorsúllyal szerepelt. Ezek a tételek nem kerültek bele a rövidített változatba.

A 17 tételes Házastársi Stressz Skála Cronbach-alfája 0,77. Az öt faktor reliabilitását is külön-külön megvizsgáltuk, ezek Cronbach-alfa értékeit a 2. táblázat mutatja be. 
2. táblázat. A Házastársi Stressz Kérdőív faktorainak reliabilitása

\begin{tabular}{|l|c|}
\hline Faktor & Cronbach-alfa \\
\hline 1. szeretet, bizalom & 0,86 \\
\hline 2. problémák & 0,81 \\
\hline 3. szexualitás & 0,78 \\
\hline 4. szívbetegség és szex & 0,74 \\
\hline 5. személyes identitás & 0,18 \\
\hline
\end{tabular}

Az utolsó faktor (melynek a személyes identitás nevet adtuk) alacsony Cronbach-alfa értéke azt jelentheti, hogy - jóllehet a hozzá tartozó két kérdés a fókomponens elemzés során külön faktornak bizonyult - e két kérdés mégsem ugyanazt méri.

A Rövidített Házastársi Stressz Skálát korábban egy pilot vizsgálatban (30-as létszámú, életkorra, végzettségre és nemre nézve heterogén, nem beteg populáción) hoztuk létre, a skála Cronbach-alfája 0,69 és szignifikánsan korrelált a 17 tételes Házastársi Stressz Skálával $(\mathrm{r}=0,86$, $\mathrm{p}<0,001)$. A rövidítésnél elsósorban azt a szempontot vettük figyelembe, hogy lehetóleg minden komponensból kerüljenek a rövidített változatba is kérdések. A 3. és 4 . faktorból nem választottunk ki tételeket, mert a szexualitással kapcsolatos kérdéseket az epidemiológiai vizsgálatban (az országos reprezentatív felmérésben) nem kívántuk vizsgálni. Viszont az elsó komponensból, mely a 17 tételes kérdôívben is a legtöbb információt tömöríti magába (a teljes variancia 32\%-át magyarázza), 3 kérdés is bekerült.

A Rövidített Házastársi Stressz Skála kérdései tehát a következóképpen álltak össze: 3 kérdés az első faktorból, 1 kérdés a másodikból és 1 kérdés az ötödik faktorból:

- HS7. Házastársa (élettársa) az önhöz legközelebb álló személy, bizalmasa?

- HS9. Vannak dolgok, amelyekról nem tudnak nyíltan beszélni egymással?

- HS10. Voltak korábban komoly problémák a kapcsolatukban?

- HS13. Problémáikat közösen szokták megoldani?

- HS5. Házastársával (élettársával) közösen töltik szabadidejüket?

Ahogy a „módszerek” részben utaltunk rá, a rövidített skálát a Kardiológiai Intézet Kockázat Vizsgálatában részt vett 137 fós szívbetegmintán is teszteltük. A kiválasztott öt tétel az eredeti skálaértékekkel korrelált, méghozzá az elsó három skálaösszege az eredeti kérdôív elsó faktorával, a negyedik tétel az eredeti kérdőív második faktorával, míg az ötödik 
3. táblázat. A Rövidített Házastársi Stressz Kérdőív tételeinek korrelációja az eredeti skálaértékekkel

\begin{tabular}{|c|c|c|}
\hline Faktor & Korreláció & Szign. \\
\hline 1 & $\mathbf{0 , 9 7}$ & 0,01 \\
\hline 2 & $\mathbf{0 , 8 2}$ & 0,01 \\
\hline 5 & $\mathbf{0 , 6 3}$ & 0,01 \\
\hline
\end{tabular}

tétel az eredeti kérdôív ötödik faktorával. Vagyis elmondhatjuk, hogy a kiválasztott tételek jól reprezentálják az eredeti kérdốiv elsó, második és ötödik faktorát (3. táblázat).

Megvizsgáltuk azt is, hogy az öt tétel skálaösszege korrelál-e a 17 tétel skálaösszegével. A korreláció 0,001 szinten szignifikáns, értéke 0,902. Tehát az eredeti skálaösszeget jól reprezentálja a Rövidített Házastársi Stressz Skála öt tételének skálaösszege. A öt tétel Cronbach-alfája az Országos Kardiológiai Intézet Kockázat Vizsgálatában is 0,69.

\section{ÖSSZEGZÉS}

Az Országos Kardiológiai Intézet Kockázat Vizsgálatának célja elsôsorban a nyitott szívmútéten átesett betegek pszichoszociális kockázati tényezőinek vizsgálata és követése. Mútét után két évvel a 17 tételes Házastársi Stressz Skála magyar változata is részét képezte a vizsgálatnak, ennek célja a skála pszichometriai jellemzóinek, belsó struktúrájának feltárása, valamint a Rövidített Házastársi Stressz Skála tesztelése.

A 17 tételes Házastársi Stressz Skála a faktoranalízis során öt különálló komponenst eredményezett: a szeretet-bizalom, a problémák, a szexuális kapcsolat, a szívbetegség hatása a szexualitásra, valamint a személyes identitás faktorokat. A tételek az egyes dimenziókban jól elkülönültek, mindössze két tételt találtunk, melyek nem tartoztak egyértelmúen egy faktorhoz, ezeket a rövidítés során kihagytuk. Egy korábbi pilot vizsgálat alapján a rövidítésnél elsôsorban azt a szempontot vettük figyelembe, hogy lehetóleg minden komponensból kerüljenek a rövidített változatba is kérdések, kivéve a 3-as és 4-es faktor kérdéseit, melyeket az epidemiológiai felmérésben nem kívántunk vizsgálni. Mivel az elsó komponens a 17 tételes kérdóívben is a legtöbb információt tömöríti magába, ebból a komponensból három kérdést is beválasztottunk a rövidített változatba. A Rövidített Házastársi Stressz Skálát az Országos Kardiológiai Intézet Kockázat Vizsgálata betegein is teszteltük. A skála öt tételének (három kérdés az elsố komponensból, egy a másodikból, egy az ötödikból) skálaösszege korrelált a 17 tétel skálaösszegével, Cronbach-alfa értéke megfeleló. 


\title{
FÜGGELÉK
}

\section{A 17 tételes Házastársi Stressz Skála magyar változata}

\author{
Kérjük, válaszoljon igennel vagy nemmel!
}

HS1. Kapcsolata a házastársával (élettársával) szeretetteli?

HS2. Kapcsolata a házastársával (élettársával) baráti?

HS3. Kapcsolata a házastársával (élettársával) rutinos (inkább megszokott)?

HS4. Kapcsolata a házastársával (élettársával) problematikus?

HS5. Házastársával (élettársával) közösen töltik szabadidejüket?

HS6. Van saját magánélete a házastársával való kapcsolaton kívül?

HS7. Házastársa (élettársa) az önhöz legközelebb álló személy, bizalmasa?

HS8. Házastársa (élettársa) Önt tartja a hozzá legközelebb álló személynek (bizalmasának)?

HS9. Vannak dolgok, amelyekról nem tudnak nyíltan beszélni egymással?

HS10. Voltak korábban komoly problémák a kapcsolatukban?

HS11. Jelenleg vannak a házastársával való kapcsolatában komolyabb problémák?

HS12. Kapcsolatukban voltak komolyabb krízisek?

HS13. Problémáikat közösen szokták megoldani?

HS14. Van szexuális kapcsolata a házastársával?

HS15. Kielégítónek találja a szexuális kapcsolatukat?

HS16. Szívbetegsége befolyásolta szexuális kapcsolatukat?

HS17. Szívbetegsége miatt megszúnt a szexuális kapcsolatuk?

\section{IRODALOM}

Baker, B., Paquette, M., Szalai, J. P., Driver, H., Perger, T., Helmers, K., O'Kelly, B., Tobe, S. (2000): The influence of marital adjustment on 3-year left ventricular mass and ambulatory blood pressure in mild hypertension. Arch. Inter. Med. 160 (22): 3453-3458.

Balog P, Dégi L. Cs. (2005): A családi támogatottság szerepe a daganatos nók pszichoszociális sérülékenységének csökkentésében. Mentálhigiéné és Pszichoszomatika, 6 (1): 17-34.

Blom, M., Janszky, I., Balog, P., Orth-Gomer, K., Wamala, S. P. (2003): Social relations in women with coronary heart disease: the effects of work and marital stress. J Cardiovasc Risk, 10 (3): 201-206.

Kimmel, P. L., Peterson, R. A., Weihs, K. L., Shidler, N., Simmens, S. J., Alleyne, S., Cruz, I., Yanovski, J. A., Veis, J. H., Phillips, T. M. (2000): Dyadic relationship conflict, gender and mortality in urban hemodialysis patients. J Am Soc Nephrol, 11: 1518-1525.

Krantz, G., Östergren, P. O. (2001): Double exposure. The combined impact of domestic responsibilities and job strain on common symptoms in employed Swedish women. European Journal of Public Health, 11 (4): 413-419.

Orth-Gomer, K., Chesney, M. A. (1997): Social stress/strain and heart disease in women. In Julian D. G., Wenger, N. K. (eds.): Women and Heart Disease. Martin Dunitz, London, 407-420.

Orth-Gomer, K., Leineweber, C. (2005): Multiple stressors and coronary disease in women. The Stockholm Female Coronary Risk Study. Biological Psychology, 69: 57-66.

Orth-Gomer, K., Wamala, S. P., Horsten, M., Gustafsson, K. S., Schneiderman, N., Mittleman, M. (2000): Marital stress worsens prognosis in women with coronary heart disease. The Stockholm Female Coronary Risk Study. JAMA, 284 (23): 3008-3014. 
Robles, T. F, Kiekolt-Glaser, J. K. (2003): The physiology of marriage: pathways to health. Physiology and Behavior, 79: 409-416.

Wickrama, K. A. S, Lorenz, F. O., Conger, R. D. (1997): Marital quality and physical illness: a latent growth curve analysis. J. Marriage Fam., 59: 143-155.

Wild, D., Grove, A., Martin, M., Eremenco, S., McElroy, S., Verjee-Lorenz, A., Erikson, P. (2005): Principles of good practice for the translation and cultural adaptation process for patient-reported outcomes (PRO) measures: report of the ISPOR Task Force for Translation and Cultural Adaptation. Value in Health, 8 (2): 94-104.

Köszönetnyilvánítás. A tanulmány az OTKA T 035169, TS-40889 (2002), TS-049785 (2004) pályázatok és az NKFP 1/002/2001, valamint az NKFP 1b/020/2004 támogatásával készült.

\section{BALOG, PIROSKA - SZÉKELY, ANDREA - SZABÓ, GÁBOR - KOPP, MÁRIA \\ PSYCHOMETRIC CHARACTERISTICS OF THE SHORTENED MARITAL STRESS SCALE}

Aims: The primary aim of the Gottsegen Gyorgy National Institute of Cardiology Survey was to investigate and follow up the effect of psychosocial risk factors on morbidity and mortality after open heart surgery. Methods: 137 patients (87 men, 50 women) completed the 17-item Marital Stress Scale, two years after the surgery. Following the factor analyses (Varimax rotation) of the 17-item Marital Stress Scale we analyzed the Shortened Marital Stress Scale also. Results: We found using factor analyses that the Marital Stress Scale (with 17 items and Cronbach's alpha 0.77) to be comprised of five different components: loveconfidence, problems, sexual relationship, the effect of heart disease on the sexual relationship and the private identity. The items on the factors were fairly differentiated with only two items not strictly related to one factor. These items were eliminated from the shortened version. Five items comprised the Shortened Marital Stress Scale: 3 items from the first component, 1 item from the second, and 1 item from the fifth component. The scale has a good correlation with the 17-item Marital Stress Scale $(r=0.902, p<0.001)$, and has an adequate internal consistency (Cronbach's alpha 0.69). Conclusion: The psychometric properties of the Shortened Marital Stress Scale are adequate.

Keywords: open heart surgery, marital stress, factor analyses, Shortened Marital Stress Scale, psychometric properties 